\title{
La metamorfosis de la pérdida en tres cuentos de Amparo Dávila
}

\author{
Metamorphosis of the loss in three Amparo Davila's \\ short stories
}

\author{
Cunuhtémoc Díaz GonzÁlez Domínguez \\ ORCID: 0000-0003-2997-9235 \\ Universidad de Colima, México \\ cdiazgonzalez@ucol.mx
}

Resumen:

Amparo Dávila es una figura fundamental de las letras mexicanas. Su cuentística explora, a través de sus personajes femeninos, las crisis y los cambios en la vida de las mujeres mexicanas durante el siglo XX. En este artículo se analizaron tres cuentos: "Música concreta", "Griselda" y "El último verano", a partir de la metodología mitocrítica, desarrollada por el antropólogo francés Gilbert Durand. Este horizonte crítico facilita exponer el tejido simbólico oculto en los cuentos elegidos, cuando los personajes padecen una pérdida como la muerte de un esposo, el final de un matrimonio o un aborto. Este quebranto en sus vidas conduce a que las personajes evoquen una metamorfosis imaginada por ellas, sea esta animal o vegetal, como un modo de resistencia ante los papeles socialmente asignados a ellas, es decir, esposas y madres.

Palabras clave:

metamorfosis, pérdida, mujer, mitocrítica, símbolo. 


\section{Abstract:}

Amparo Dávila is a fundamental figure of Mexican letters. Her storytelling explores, through her female characters, the crises and changes in the lives of Mexican women during the twentieth century. This article analyzes three stories, "Música concreta", "Griselda" y "El ultimo verano", using myth-cristicism as methodology, which was developed by the French anthropologist Gilbert Durand. This critical horizon facilitates exposing the mythical-symbolic fabric hidden in the chosen short-stories, when the characters suffer a bereavement, like the death of a husband, the end of a marriage or an abortion. This collapse of their lives leads the characters to evoke an imagined metamorphosis, whether animal or vegetable, as a way of resisting the roles socially assigned to them, that is, wives and mothers.

Key words:

metamorphosis, loss, woman, myth-criticism, symbol.

DOI: https://doi.org/10.36798/critlit.vi21.322

Recibido: 26 de febrero de 2020

Aceptado: 04 de mayo de 2020

\section{Preámbulo}

Amparo Dávila (Zacatecas, 1928) crea en su narrativa un universo que es siniestro por su aparente inocuidad. Las páginas que componen "Música concreta" — que da nombre al mismo libro publicado por primera vez en 1961_, "Griselda" y "El último verano" —ambos pertenecientes a Árboles petrificados (1977) — son el hogar de personajes que, si existieran fuera de la ficción daviliana, no tendrían la posibilidad de sobresalir de la mediana cotidianidad: una esposa que descubre la infidelidad de su marido, una madre fatigada por la maternidad, una viuda que no logra abatir las penas del duelo. Aunque estremecen las pérdidas que sufren los personajes femeninos de los cuentos, cuya vida ordinaria y rutinaria se fractura de manera irremediable, también, como acertadamente reflexionan al 
respecto Marisol Luna y Víctor Díaz (2018), las mujeres que Dávila construye no existen fuera de los espacios íntimos que las limitan "y su ausencia no será motivo de inquietud para este mundo hostil, lleno de preocupaciones y problemas en el que ocurren todas las tragedias, pero en donde algunas son tan personales y profundas como invisibles" (207). Ese mismo rasgo de lo íntimo y ordinario es la potencia diegética de los tres cuentos: la pérdida y el duelo magnificados en las mentes acosadas por el horror que emana de sus vidas cotidianas y aisladas del mundo.

En lo que se refiere al horizonte teórico-metodológico, se anticipa que la mitocrítica, como metodología de análisis, requiere una lectura minuciosa del texto cultural (literario en este caso) para poder localizar obsesiones, recurrencias y repeticiones en el discurso que se está analizando (Durand, "La mitocrítica paso a paso" 106). Ya que se obtienen los datos, Gilbert Durand introduce un paso al que llama cualificación, en el cual se concede una valoración a un objeto, acto o situación (Durand 110). Así, el discurso, literario en este trabajo, a partir de la cualificación de las recurrencias podrá ir exhibiendo redes de imágenes de coherencia sincrónica (isotopías), dentro de una narración diacrónica (Durand 111). La obra literaria se puede descifrar desde los símbolos, porque las cualificaciones se revelan como conjuntos simbólicos que permiten hacer lecturas sincrónicas, pero también como constelaciones de imágenes que se ordenan en una estructura simbólica (Durand 112).

\section{La metamorfosis}

El sujeto que pierde algo o a alguien, por ejemplo, un matrimonio que se desgaja, un hijo o un compañero de vida que fallece, no solo pierde, sino que queda perdido, a la deriva por su rutina resquebrajada. Este hecho es un punto del que eclosiona un proceso de metamorfosis física, real o imaginada, en las mujeres que pueblan los tres cuentos sobre los que reflexiona este trabajo. El cambio de las formas físicas, el trocamiento de los cuerpos o la apariencia de convertirse en un animal o un vegetal es una constante en los tex- 
tos culturales que ha construido el género humano. Metamorfosis del poeta latino Ovidio constituye el canon clásico de versos que guardan la simiente de los mitos grecolatinos que aún nos seducen. Mitos mesoamericanos como Mayaguel que, asesinada por su abuela por escaparse con Quetzalcóatl, se transforma en maguey, u obras como La metamorfosis de Franz Kafka ejemplifican esa constante.

El análisis de los cuentos elegidos para este trabajo se llevará a cabo siguiendo la metodología mitocrítica de Gilbert Durand. El proceso analítico se centrará, esencialmente, en seis imágenes como punto de partida: el sapo, las tijeras, el gusano, el fuego, los ojos y los lirios. La importancia de estas imágenes radica en que son resultado del acto metamórfico, pero, a su vez, se pueden entender como díadas que se aniquilan y se encuentran en la diégesis de los relatos como el acto final de los personajes femeninos; empero, no resultan definitorias, sino que se cargan de importancia simbólica en el tejido narrativo.

\section{“Música concreta": el sapo y las tijeras}

"Música concreta" inicia con el encuentro entre dos viejos amigos y desde la primera línea son introducidos los personajes que tejen el relato: “Se parece a Marcela” piensa Sergio deteniéndose” (97). La narración sugiere que desde hace tiempo no se ven y el hombre observa que su amiga se mira con cierto desmejoramiento. A partir de este hecho Sergio se asume como un protector que va siguiendo la decadencia anímica de ella.

Marcela es una mujer casada cuyo matrimonio parece haber llegado a su fin, ya que su marido, al que jamás se dibuja en la narración ni se le cede la voz, mantiene una relación extramatrimonial con otra mujer: "Luis me engaña y todo se ha roto entre nosotros . . . Ha sido un golpe tremendo, como quedarse de pronto caminando sobre la cuerda floja, sin tiempo ni espacio donde situarse" (100). Su interlocutor, Sergio, se interesa entonces por saber más acerca de esa situación que tiene en condiciones tan dolorosas a su amiga. Se sorprende cuando ella le informa que, por las noches, de los 
naturales sonidos, uno sobresale para atormentarla y se da cuenta de que este emerge de la amante de su esposo, que la visita cuando duerme y, por consiguiente, cuando se encuentra más vulnerable: "[C]omencé a distinguir uno que sobresalía de entre los demás y que cada vez era más fuerte y más preciso, cada vez se acercaba más hasta llegar a mi ventana ... así todas las noches, igual, sin descanso, una vez la descubrí, eran sus ojos, yo los conocía" (102).

Este fragmento es importante porque se nombra un rasgo que eclosiona la metamorfosis a lo largo de todo el relato: los ojos. Más adelante, Marcela deja claro que ya conoce a la amante y que la reconoce a partir de sus inusuales características: "Un día llegaron juntos en el auto de Luis, la alcancé a ver bien, los ojos saltones, inexpresivos, los mismos ojos que descubrí bajo mi ventana entre las hierbas..." (103).

Es necesario acotar que Marcela descubre que la amante es una costurera. Esto implica, por un lado, una distinción económica entre ambas, pues Marcela parece pertenecer a cierta clase acomodada y urbana, que tiene personal de servicio en su casa y hace vida social en restaurantes y cafeterías; por otro lado, al ser esposa, cumple debidamente con el papel estereotipo, mientras que la amante, al ejercer su sexualidad sin la necesidad del matrimonio, desobedece un mandato social asignado a las mujeres mexicanas de los años 60.

Respecto al matrimonio de la protagonista, aparentemente fracturado, y al papel de amante de una mujer que rechaza la forma de organización familiar (que Marcela representa), es necesario atender que, en México, el siglo XX fue el momento de consolidación del matrimonio. Además, en la primera mitad del siglo XX y hasta finales de los años 60, el divorcio y la separación tenían una ínfima repercusión (Quilodrán 40). Igualmente, como parece resultar lógico, el sexo era visto como una obligación para las mujeres, independiente del placer, ya que la reproducción de la sociedad se institucionalizaba, justamente, a través del matrimonio (Esteinou 72). Así, los roles asignados a las mujeres eran los de esposas y madres. En cierto modo, en "Música concreta", Marcela y la amante manifiestan cierto grado de rebeldía a estos papeles exigidos, la primera por cuestionar su vida matrimonial y la segunda por rechazarla. 
El desarrollo de la diégesis avanza in crescendo paralelamente al desequilibrio de Marcela. Conforme Sergio va averiguando más acerca de la misteriosa mujer que acecha a su amiga, se encuentra con que la descripción acerca de ella se asemeja a la de un batracio. Marcela directamente expone el miedo al acoso de la amante al mismo tiempo que la construye de forma teriomórfica: "No, Sergio, no son mis nervios, es su presencia ahí bajo mi ventana todas las noches, ese croar y croar toda la larga noche" (103). Cuando Sergio exige más detenimiento sobre aquello de lo que está hablando, si de una mujer o un animal, Marcela responde: "De ella, Sergio, del sapo que me acecha noche tras noche, esperando sólo la oportunidad de entrar — y hacerme pedazos, quitarme la vida de Luis para siempre" (103).

En este punto puedo esgrimir dos afluentes que abrevan de la metamorfosis. En primer lugar, la esposa, Marcela, es encontrada en condiciones que fueron preocupantes para Sergio; es decir, hay un proceso de cambio físico y anímico como puede ser apreciado en el fragmento siguiente: "ya me destrozó al arrebatarme a Luis, ¿qué más quiere?, la noche entera croando, croando horriblemente, sin parar, afuera y dentro de los oídos tengo su croar, su croar estúpido y siniestro..." (108). En segundo lugar, el proceso de desarrollo del batracio mismo es evocado, primero como sonido nocturno, después como un sapo que logra entrar en casa de Marcela: “ahí estaba con sus enormes ojos que parecían estar ya fuera de las órbitas a punto de lanzarse sobre mí, lo sé por las patas replegadas en actitud de salto" (107), y posteriormente por la apoteosis teriomorfa, que sucede al final de la narración y que se analizará más adelante.

Hasta aquí es necesario anticipar una pregunta, ¿por qué si la costurera es una mujer se presenta como un sapo y no como una rana? Aunque parece superflua la elección de ese sustantivo en lugar de rana, que pareciera más acorde, es justamente el nódulo que condensa la potencia simbólica del texto.

En "Macario" de Juan Rulfo, los anfibios, que también poseen un papel protagónico, sirven para ejemplificar la díada opuesta de ambos anuros: "Las ranas son verdes de todo a todo, menos en la panza. Los sapos son negros ... Las ranas son buenas para hacer 
de comer con ellas. Los sapos no se comen; pero yo me los he comido también" (98). Aunque se cubre con los mismos rasgos de la rana: mutación de la tierra en agua o, al contrario, la resurrección y la fecundidad por sus estadios de crecimiento (Cirlot 381), el sapo representa su contraparte oscura, su antítesis. Al mismo tiempo, el sapo comparte con el basilisco una peculiaridad que fascina: su mirada (Cirlot 399). Si, como vemos en el cuento rulfiano, la rana es verde y lisa, y el sapo es negro y rugoso — aspectos antitéticos-, naturalmente, la costurera que acecha a Marcela se transforma en sapo y no en rana, puesto que representa los aspectos negativos de aquel y no los positivos de esta. Sin embargo, existe, como en casi todos los cuentos de Amparo Dávila, un rasgo siniestro y hasta sobrenatural, pues el sapo ingresó a la casa de Marcela una noche, y ella apenas tuvo tiempo de cerrar la puerta: "en el mismo momento la oí estrellarse contra la puerta escuchando, gemía dolorosamente, después oí cómo se iba yendo con su sordo golpear, sus cortos saltos pesados" (107). El traslado de la amante a la casa de la esposa ocurre como una acción real para la protagonista.

Es necesario recurrir también a una tradición que asocia a los sapos con la brujería, como representación del demonio, no solo porque estos portan cuernos sobre su frente. Daniel Oliveras de Ita, en La vida doble: nabualismo, brujería y terapéutica ritual en la chinantla media, llega a conclusiones semejantes respecto a este anfibio, pues el sapo pertenece a un grupo de animales considerados hematófagos junto con la comadreja y el murciélago, los cuales se consideran consumidores de la fuerza vital. Los brujos utilizan estos animales para replicar en ellos lo que desean ocurra en las personas, como coser los hocicos, lacerarlos o ahogarlos como una forma de dañar al otro (Oliveras 166). A la luz de esto, podría entenderse el sapo en el hogar de Marcela como una entidad enviada por la amante para consumirla. Marcela parece dar cuenta de su debilitamiento y la novia de Sergio, Velia, personaje que aparece a la mitad de la narración, lo confirma, pues: "encuentra a Marcela muy desmejorada y como ensombrecida. Tal parece que hubiera perdido, por completo, el interés de su persona y en todo lo que la rodea" (105). 
Gilbert Durand, en Las estructuras antropológicas del imaginario (2012), realizó una esquematización detallada de imágenes que edifican imaginarios simbólico-míticos y las clasificó en dos regímenes: diurno y nocturno. Específicamente, las imágenes que refieren rasgos de los símbolos teriomorfos se clasifican en el régimen diurno. En el caso del simbolismo animal conlleva una visión negativa y maléfica (Durand 87). Además, “el animal es susceptible de ser sobredeterminado por características particulares que no se vinculan directamente con la animalidad" (Durand 74). El sapo, como ya se ha sugerido en líneas previas, detona su fuerza simbólica, no únicamente por la evocación tenebrosa de su fisonomía, sino por la indiferencia de su mirada, lo que lo ha ubicado como un ser malévolo que es incapaz de la bondad.

La mitocrítica exige una revisión de redundancias, que ha dejado constancia en la construcción de una metamorfosis animal, de mujer a batracio en este caso; pero este proceso va acompañado necesariamente de una lectura analógica. De esta manera, la parte que nos es conocida del símbolo (la tangible) nos lleva a otra que permanece oculta. El símbolo reúne el sentido simbólico con lo que refiere (García Peña 31). El sapo por sí mismo, en la narración, es una imagen con sugerencias interesantes —algunas ya se revisaron-, pero solo tenemos conocimiento material (el sustantivo) de una parte que sugiere o revela y de otra que nos permanece oculta y que únicamente se puede intuir en el tejido literario.

Finalmente, lo que comenzó como un proceso de cambio análogo a la metamorfosis del batracio, concluye con una transformación completa frente a Sergio quien, desesperado por la condición debilitante en la que se encuentra Marcela, decide encarar a la amante y exigirle que deje de acosar a su amiga. La costurera simula desconocer a su víctima y Sergio se da cuenta que ella está consciente de sus acciones en contra de Marcela, su cara es la que la delata:

En el rostro de ella se medio dibuja una sonrisa entre burlona y despectiva, dice algo que Sergio no alcanza a escuchar bien, algo que él interpreta como 'no sé de qué habla'. Él siente 
que no se le puede oír porque habla como para adentro de ella misma. (110)

Cuando la voz narrativa explica que habla para dentro, es decir, que las palabras de la costurera no son audibles porque se quedan atrapadas dentro de ella, remite a dos cosas: por un lado, al opaco sonido que los sapos emiten, aparentemente sin despegar los labios; y por otro, a la animalización y pérdida del habla que la costurera comienza a sufrir, ya que la sonrisa burlona puede ser únicamente o un esbozo de risa o el natural gesto de los anuros.

Más adelante, la mirada del narrador se detiene en el rostro. En este punto, lo que anteriormente podría haber sido una evocación del batracio se vuelve siniestro para el personaje que testifica la transformación:

Ella sólo lo mira y lo mira fijamente, de vez en cuando él ve la misma sonrisa, su utilizada sonrisa de máscara que le adelgaza aún más los labios alargándolos [. . . la cara es demasiado grande para su corta estatura, no tiene casi cuello, como si estuviera la cabeza pegada a los hombros... (111)

La parte oculta del símbolo comienza a desvelarse. La sonrisa, los finos labios que se alargan y parecen abarcar la cara por completo infieren el arquetipo del continente y contenido, el cual cobija los símbolos de la gulliverización y el engullimiento (Durand 222). La imagen sobredeterminada trasciende los límites de la palabra que la origina (sapo); si se hace un ejercicio y se lo imagina, sobresalen los ojos, las patas y la boca, pero es esta última la que detona múltiples rasgos míticos, para los chinos, por ejemplo, es un sapo el que devora al sol (Durand 91). Solo se puede engullir lo que es mínimamente posible, por eso se concibe el empequeñecimiento o gulliverización. En "Música concreta”, Marcela es acechada por el anfibio y el temor la disminuye, la desmejora. En cierto modo son las características teriomorfas las que actúan para empequeñecerla metafóricamente, para convertirla en una presa frente a la enorme boca que representa la amante que devora su vida. 
La imagen de la boca monstruosa se acentúa casi al final del cuento, cuando Sergio se da cuenta de que ya no es una mujer quien se encuentra frente a él: "los labios son una línea de lado al lado de la enorme cabeza, se están inflando de silencio” (111). Se debe recordar que, en este punto de la narración, no se escuchan palabras de la costurera, sino que se acumulan los sonidos dentro de su cuerpo, lo que provoca que se infle al mismo tiempo que resuena su "estúpido y siniestro croar y croar y croar, con ese olor a cieno que despide, ese olor a fango putrefacto" (111). Como puede notarse en este fragmento, se recurre a la repetición de la onomatopeya para producir la sensación de acrecentamiento, de potencia y, por consiguiente, de disminución de quien observa.

Sergio se da cuenta que el monstruo batracio frente a sí busca agredirlo: "sus miembros se repliegan, yo sé que se preparan a saltar sobre mí, inflada, croando, moviéndose pesadamente, torpemente..." (111). La metamorfosis encuentra su punto culminante, pero también el más siniestro. El hombre, al sentir el horror y la vulnerabilidad, tiene la necesidad de defenderse; logra ver unas tijeras (la amante es costurera, después de todo) y ataca al sapo: "clava, hunde, despedaza...El croar desesperado empieza a ser cada vez más débil como si se fuera sumergiendo en una agua oscura y densa, mientras la sangre mancha el piso del cuarto" (111). La elección léxica de la voz narrativa connota el estanque, el natural hogar de los anuros, pero acaba de ser introducido otro elemento fundamental en el texto, es el que libera a Marcela del horror al que ha sido sometida: las tijeras.

El sapo y las tijeras son una díada construida por opuestos, uno de los cuales es la herramienta aniquiladora del otro. Juan-Eduardo Cirlot en su prominente Diccionario de símbolos (1992) ofrece con precisión algunos rasgos que emiten las tijeras, las cuales son "atributo de las místicas hilanderas que cortan el hilo de la vida de los mortales. Por ello, símbolo ambivalente que puede expresar la creación y la destrucción, el nacimiento y la muerte" (442). Las tijeras, a su vez, se recubren de un hálito semántico que evoca el arma asesina, ya no solo la herramienta propia de la costurera. Las tijeras se cargan de un significado sugerido por la verbalización de la muerte en el 
cuento. Como arma, existen a partir del encuentro con el monstruo. A la vez, su filo recuerda a la espada que, como toda arma, posee, por su naturaleza, reminiscencias fálicas (Chevalier 139).

Gilbert Durand clasifica las armas cortantes en el régimen diurno y también expone que, como símbolos diairéticos, las armas que separan el bien y el mal tienen una función fálica (Durand 166). Asimismo, es un hombre, Sergio, quien sostiene el arma para asestar sobre el batracio las punciones mortales. Aunque metamorfoseada en sapo, es un personaje femenino sobre quien se blande el filo hiriente; es decir, en el plano diegético se expone a un hombre que asesina a una mujer. Además, aunque no es un cuento que muestre una sanción moral, la metamorfosis que otorgó a la costurera la oportunidad de trascender el plano de personaje secundario (no únicamente por costurera sino por la semiclandestinidad de ser amante) para llevarla al punto central del escenario de la historia, es al mismo tiempo la que la elide.

\section{"E1 último verano": el gusano y el fuego}

Este cuento que forma parte de Árboles petrificados (1977) es la historia de una mujer fatigada por la maternidad y por su rol de esposa. Ya anteceden, acertadamente, dos estudios importantes que están de acuerdo en que la narración configura el estereotipo de la madre (Luna Martínez 2008 y Gutiérrez Piña 2017), por lo que este trabajo no estará enfocado únicamente en el análisis de la maternidad, sino en sus consecuencias simbólicas.

El cuento comienza exponiendo la juventud de la protagonista detenida en el marco de una fotografía que contrasta con la imagen que el espejo ahora detenta de ella; es decir, una mujer que se muestra envejecida y cansada, con un rostro "donde empezaban a notarse las arrugas y el poco cuidado o más bien el descuido de toda su persona: el pelo opaco, canoso, calzada con zapatos de tacón bajo y un vestido grueso gastado y pasado de moda" (205). Esta mujer, cuyo nombre es omitido probablemente como una universalización de la maternidad, asume su decadencia como un proceso natural 
de la menopausia. Este estado de la vida femenina la hace sentirse como "una sombra que se irá desvaneciendo lentamente" (205).

El título del cuento hace referencia a que justo al principiar el verano es que la mujer comienza a sentirse mal: mareos, pérdida de apetito y náuseas la obligan a visitar a su médico. Contrariamente a lo que imagina, no es la esterilidad la que la acecha, sino su vientre fecundo que anuncia un séptimo hijo. La voz narrativa es contundente respecto al sentimiento de la protagonista: "no experimentó ninguna alegría, por el contrario una gran confusión y una gran fatiga" (206). Dos son los elementos que sobresalen en este momento de la narración. Por un lado, la mujer ya tiene una considerable cantidad de hijos; sabemos cuántos exactamente porque declara que "es pesado después de siete años volver a tener otro niño, cuando ya se han tenido seis más” (206). Es interesante que el siete vuelve a repetirse $y$, justamente, en lo concerniente a la temporalidad; el número siete relaciona las series esenciales:días de la semana, virtudes, pecados (Cirlot 305); además, aunado a los ciclos, Cirlot afirma que, como símbolo, alude directamente al dolor (330). Por otro lado, el desasosiego que la maternidad causa a la mujer está intrínsecamente relacionado con el agotamiento. En este sentido, Gutierrez Piña explicita la fatiga como actor fundamental de la narración, pues esta deja de ser únicamente el resultado de las labores domésticas cotidianas de la madre y se vuelve un cansancio primordial de orden femenino y biológico. Lo importante es la seña de hartazgo que connota el cuerpo de la mujer (143), resultado también de su embarazo.

La fatiga es un elemento primordial que va a ir configurando elementos ocultos. El rastreo mitocrítico, como se explicó previamente, se detiene en las redundancias obsesivas. En el caso específico del cansancio, este es verbalizado a lo largo de la diégesis: "Pasaban los días, las semanas, y seguía sin encontrar resignación y esperanza. La fatiga aumentaba con los días y una gran debilidad la obligaba a recostarse, en ocasiones, varias veces durante el día" (207). Como madre de seis, con un esposo que no aporta al cuidado, tal como lo establece la voz narrativa, el lector aduciría como cotidiano aquel agotamiento; pero la elección de las palabras que 
lo construyen, las marcas que lo configuran, es lo que despoja el revestimiento y expone una imagen simbólica soterrada. No es el cansancio cotidiano el que la aqueja, sino el hijo que ocupa el vientre el que la desmejora, la desvitaliza.

Los elementos que van otorgándole una valoración negativa a la maternidad de la personaje son concluyentes — “otro hijo más no es un premio, sino un castigo" (207) - y se van diseminando por la narración. La preñez parece incidir en la percepción que tiene sobre su entorno: "Hasta ella llegaba el perfume del huele de noche que tanto le gustaba, pero que ahora le parecía demasiado intenso y le repugnaba" (208). La lastimosa situación que evoca una relación parasitaria finalmente concluye una noche:

Estaba observando indiferente a las luciérnagas, que se encendían y apagaban poblando la noche de pequeñas y breves lucecitas, cuando algo caliente y gelatinoso empezó a correr entre sus piernas. Miró hacia abajo y vio sobre el piso un ramo de amapolas deshojadas. (208)

Resulta valiosa la elección de adjetivos y verbos en el fragmento anterior, ya que las palabras "caliente" y "gelatinoso" dirigen la lectura a pensar en algo vivo y acuoso y, aunadas al verbo "correr", que en este caso se utiliza como metáfora de descender, conllevan la posibilidad del ser que huye, que escapa. Las flores deshojadas son un elemento que evoca el aborto. La imagen de las flores está sobredeterminada y convoca la pérdida del hijo, pero este recurso se puede encontrar en otras obras. Por recordar solo una, en Santa de Federico Gamboa podemos leer que "con las heladas del invierno una mata de claveles rojos que por sí misma atendía y regaba, amaneció marchita una mañana, roto el tallo, desperdigados los pétalos, simulando extrañas gotas de sangre, lenta hemorragia que hubiese acabado con la planta" (50). En este caso, los claveles deshechos son la premonición de un aborto futuro; empero, el ejemplo sirve para demostrar la función simbólica de los pétalos desprendidos.

Es necesario atender un término que se precisa en este análisis y que es fundamental en las lecturas mitocríticas, la isotopía, la cual 
Greimas define en Semántica estructural (1987) como "un conjunto redundante de categorías semánticas que hace posible la lectura uniforme del relato" (188). Greimas fue el primero que propuso el término. Sin embargo, a lo largo del tiempo, cada aproximación crítica que lo utiliza actualiza el concepto y lo acerca a la perspectiva teórica con la que observa el texto. García Peña, por ejemplo, conceptualiza la isotopía como "la reiteración o recurrencia de elementos semánticos que conforma una constante de sentido o línea de significación que dota de coherencia interna la poética del texto" (Etnoliteratura 64). Personalmente considero la isotopía como la constitución de una red semántica a partir de palabras que orientan la conformación de una unidad icónica.

La isotopía que se va construyendo en "El último verano" es la de una relación huésped y parásito. Un ser interno iba consumiendo a la mujer al grado de que, previo al aborto, ya ni siquiera conseguía dormir: "el alba la sorprendía con los ojos abiertos aún y las manos crispadas por la angustia" (207). La imagen del parásito logra condiciones apoteósicas hacia el final de la narración, pero las redundancias se van capturando a lo largo del texto y construyen dicha relación. La acción fundamental de enterrar los restos de la criatura perdida es encomendada por la madre a su marido, del que, dicho sea de paso, sí sabemos su nombre, tan habitual que puede representar también el estereotipo del padre: "Antes de caer en el sueño, le pidió a Pepe que envolviera los coágulos en unos periódicos y los enterrada en un rincón del huerto, para que los niños no los vieran" (208).

Aunque, aparentemente, la mujer posee cierta calma con respecto al suceso angustioso que recién había pasado a formar parte de su vida, acepta cierto grado de dolor en la pérdida, pero a su vez, la tranquilidad de liberarse de aquella tortuosa relación perinatal: "no pudo menos que experimentar un gran descanso por haber salido de aquella tremenda pesadilla. Claro que le dolía que hubiera sido en una forma tan triste, tan desagradable, pero las cosas no son como uno las desea" (208). Sin embargo, esta transición de sosiego posterior al aborto es apenas el punto de quiebre que llevará a la mujer al desequilibrio y a la destrucción de su propia existencia. 
La acción que desencadena el final funesto se presenta cuando la mujer le pide a uno de sus hijos pequeños que traiga algunos jitomates de su jardín. El niño se niega y profiere: "No, mami, porque ahí también hay gusanos" (208). Es necesario resaltar que la mujer está viviendo un duelo y que toda la responsabilidad de la pérdida recae sobre ella. El propio médico que la revisa posteriormente, le espeta: "Te recomendé mucho que descansaras, hija, que no te fatigaras tanto" (208), recriminación que sobra teniendo en cuenta todas las actividades que, sin ser opcionales, debía realizar en su cotidianidad. El duelo perinatal se considera, lastimosamente, como desautorizado, porque, en principio, el aborto aún es un tema tabú. Esta pérdida no se reconoce como válida, mucho menos se permite que la mujer la exprese, ni se espera que esta reciba apoyo de su entorno familiar, se vive en soledad (Martos-López et al. 302).

La voz narrativa expresa, con acertada claridad, lo mismo que demuestra la experiencia clínica tras el duelo perinatal: "Comenzaron a zumbarle los oídos y todos los muebles y las cosas a girar a su alrededor, se le nubló la vista y tuvo que sentarse para no caer. Estaba empapada en sudor y la angustia le devoraba las entrañas" (208). La persona que vive los duelos perinatales sufre

shock e insensibilidad, aturdimiento y dificultades para funcionar con normalidad ... tiene conductas de búsqueda, con irritabilidad, labilidad, debilidad y sentimientos de culpa . . . desorientación y desorganización de la vida cotidiana, con sensación de vacío y desamparo. (Martos-López et al. 302)

La zozobra que siente la protagonista no se enfoca en su propio dolor o en la culpa de no haber deseado el embarazo (su duelo está desautorizado), sino en una cosa que pareciera nimia y que es, sin embargo, como ya se adelantaba, el punto de quiebre: que su esposo torpe no haya enterrado con suficiente profundidad los restos de su maternidad arrebatada, lo que se verifica cuando ella solo atina a decir: "pero qué horror, qué horror, los gusanos saliendo, saliendo..." (208). Con la imagen del gusano se completa la isotopía del ser que se alimenta de otro. En cierto modo, lo que la voz narrativa 
ha estado ofreciendo en marcas a lo largo de la diégesis queda expuesto, pero también para la mujer queda evidenciado el horror al que sigue presa, pues ahora se da cuenta de que aquello, que por unos días la abandonó, vuelve en forma de gusanos para hacerse presente, como si no hubiese escapatoria.

La imagen del gusano tiene elementos distintivos que se comprenden por el contexto del cuento. En definitiva, sus rasgos lo instituyen como una figura de naturaleza libidinal asociada a la muerte. Por pertenecer a lo subterráneo su tarea describe los ciclos de descomposición biológica (Cirlot 232). Gilbert Durand, al revisar diferentes autores, nota que el gusano es utilizado como representación de un monstruo fálico cuya complementación femenina es la araña (77); baste pensar cómo repta y horada la tierra (todo elemento que la hiende se dirige a lo fálico, como las herramientas agrícolas) o cómo las larvas agrietan la carne de los cadáveres para alimentarse para comprender la relación entre el gusano y el falo.

La ansiedad, el miedo y la sensación de sentirse acechada provocaron que la rutina de la mujer se volcara únicamente a estar alerta, como si esperara a algo o a alguien. Ella está consciente del encuentro irremediable. Es como si la protagonista se preguntara si podría ser capaz de volver en forma de gusanos aquel hijo rechazado para seguirla devorando. La cita ocurre una tarde en la que se encuentra sola en su casa:

Cerca de las seis de la tarde alcanzó a percibir como un leve roce, algo que se arrastraba sobre el piso apenas tocándolo; se quedó quieta sin respirar... sí, no cabía la menor duda, eso era, se iban acercando, acercando, acercando lentamente, cada vez más, cada vez más... y sus ojos descubrieron una leve sombra bajo la puerta, sí estaban ahí, habían llegado. (209)

Un cadáver, paradójicamente, es un sitio que reverbera de vida, por lo tanto, la protagonista se cuida de no convertirse en uno, pues lo que quiere es no encontrarse en el papel de alimento de los gusanos que la han encontrado y que planean culminar lo que, previamente, iniciaron como embrión en el vientre. La forma, para culminar su 
cometido, es absolutamente fulminante y simbólica, pues ella tomó "el quinqué de porcelana antiguo que fuera de su madre . . desatornilló el depósito de petróleo y se lo fue vertiendo desde la cabeza a los pies ... con el sobrante roció una circunferencia, un pequeño círculo a su alrededor (209). El fuego, si bien es destructivo, es necesario para la renovación; el fuego y la vida se equilibran porque el primero necesita de lo vivo para existir. El fuego destruye el tiempo y trasciende lo humano (Cirlot 210). Además, como purificador, rompe la confusión de la mente (Durand 178).

Finalmente, la metamorfosis encuentra su instante de eclosión, funesta, pero liberadora, cuando la mujer se inmola mediante el fuego al encender el petróleo de la lámpara: "los alcanzó a ver entrando trabajosamente por la rendija de la puerta... pero ella había sido más lista y les había ganado la partida. No les quedaría para consumar su venganza sino un montón de cenizas humeantes" (209). En este caso, la metamorfosis, primero del hijo perdido que vuelve como gusanos y, posteriormente, de la madre que mediante el sacrificio por fuego se convierte en cenizas, es el recordatorio de una falta, de un rechazo al papel socialmente asignado a ella: ser madre, pero también expone el ansiado encuentro con la libertad que le otorga la muerte.

\section{"Griselda": los ojos y los lirios.}

Este cuento fue publicado por primera vez en Árboles petrificados (1977), es de corta extensión, y es la conversación entre una mujer joven, cuyos padre y novio acaban de morir, y una mujer madura que no logra recuperarse de la muerte de su esposo. Por las tardes, la joven sale a caminar y siempre es atraída por una casa ruinosa pero con cierta belleza y distinción que la seducen y la obligan a investigarla. Cuando logra atravesar la maleza se encuentra con la antigua dueña y, como ella se da cuenta de su intromisión, decide conocerla en lugar huir.

Es necesario atender la descripción del espacio que parece ser la señal premonitoria del desenlace fatídico. Cuando la joven ingresa 
en la casa, un pájaro la asusta y su suéter negro se queda atrapado en las espinas de un rosal. Este insignificante acontecimiento solo expone la sugerencia de una naturaleza agreste y malvada, como después se observará. Martha, la mujer joven, descubre también una alberca que está oculta entre la espesura, sus aguas estancadas esconden una imagen simbólica que se apodera del cuento.

Aunque podría caerse en el error de considerar el jardín descuidado únicamente como un escenario en el que se desarrolla el diálogo entre las dos mujeres, este es en realidad el elemento que oculta la estructura simbólica de la pérdida. Cuando la joven Martha observa a la dueña de la casa, como ya adelantaba antes, la voz narrativa la presenta de la forma siguiente: "Una mujer vestida de negro se encontraba sentada en una banca a la sombra de un álamo" (199). El álamo, como imagen fundamental en el fragmento, adelanta la tristeza y malevolencia de la historia; desde la antigüedad clásica, el álamo es el árbol consagrado al infierno, la doble tonalidad de sus hojas muestra la dualidad, asimismo, algunos personajes mitológicos se transforman en álamos como castigo, pero por sobre todos sus rasgos, resalta como guardián del tiempo pasado y como figura clave del dolor y el llanto (Chevalier 69).

Cuando ambas mujeres se encuentran una frente a la otra, la dueña de la casa, al presentarse, otorga una información fundamental para la comprehensión simbólica del cuento: “-Me llamo Griselda — dijo por toda presentación la mujer que usaba unas gruesas gafas oscuras" (200). Además de su nombre, que intitula el cuento, la voz narrativa se centra en un detalle que cobra relevancia al final de la narración, como sucede en los cuentos anteriores, en este caso, las gafas oscuras. La importancia de este accesorio se puntualiza cuando se ofrece una descripción de Griselda: "No usaba maquillaje y las gafas impedían apreciar bien sus facciones. Sin embargo, se podía advertir que aún era una mujer guapa" (200).

Con acierto, Adriana Álvarez localiza como estrategia narrativa en los cuentos de Dávila la respiración para crear el miedo, pero también se enfoca en otra que, en lo personal, me parece aún más importante: los ojos y la mirada, los cuales, dice, se vuelven una herramienta de persecución que invade todos los rincones (1). El én- 
fasis sobre los ojos se ofrece en diversos momentos de la narración, especialmente cuando Griselda le acerca un medallón que contiene una foto de ella y su esposo. Martha se da cuenta de la belleza inigualable de la mujer atrapada en el retrato: "Con enormes ojos de un extraño color azul, gris, verde. Un color increíble de humo verde azul. El cabello oscuro le caía sobre los hombros enmarcando un óvalo perfecto, y los extraordinarios ojos que Martha no podía dejar de admirar" (201).

La diégesis va hilvanando marcas obsesivas que van construyendo una isotopía que el lector va desvelando a partir de la relación entre las plantas y los ojos. En la conversación que desarrollan ambas mujeres surge la recriminación por parte de la hija, que se considera presa de la rutina materna, ya que el duelo por el que atraviesa su madre (por la muerte del esposo) la ha condenado a sus lamentos constantes y a su tristeza. En algún momento de la charla, Martha piensa que: "Ya tenía suficiente con haber perdido a su padre; y miraba el estanque invadido de lirios acuáticos" (202). Este tipo de elementos introducidos son los que van hilvanando el tejido del que, posteriormente, provendrá el horror.

Ambas mujeres relatan sus historias de pérdida, pero la que destaca porque detona la metamorfosis es la de Griselda. La dueña de la casa narra a Martha que fue una noche de lluvia cuando la tragedia de la muerte de su esposo sucedió y, al mismo tiempo que va describiendo los acontecimientos, el jardín de la vieja casona comienza a cambiar como si tuviera una relación intrínseca con la protagonista: "El olor de los jazmines y de las madreselvas comenzaba a ser demasiado fuerte, tanto que, de tan intenso, se iba tornando oscuro y siniestro, como la tarde misma y los árboles y el agua ensombrecida del estanque" (203). El perfume embriagador es la antesala del desesperado acto de dolor que Griselda confiesa; la noche en la que su esposo, el hombre que se enamoró de sus ojos, murió, ella decidió que ya no tenía necesidad de ellos, cuya única función era admirarlo:

—Aquella noche decidí arrancarme los ojos... — - se llevó el pañuelo a la cara ahogando un grito. 
-...me arranqué los ojos y los arrojé al estanque para que nadie más los viera — decía Griselda quitándose las gafas y cubriéndose el rostro con el pañuelo para sollozar sordamente. (203)

Todo duelo es un proceso que acompaña la pérdida, en el caso concreto que se revisa aquí, de un familiar; sin embargo, existe la posibilidad, en algunos casos, de que ese proceso derive en lo que se denomina duelo patológico. Un elemento que coadyuva a que se patologice el duelo es la culpa. En las muertes de gran impacto, como la del esposo de la protagonista a causa de un accidente en una tormenta, la culpa suele estar presente con bastante intensidad, acompañada de confusión y sensación persecutoria. Otro agente que nutre el duelo patológico es cuando se siente culpa por vivir. La culpabilidad anuncia, definitivamente, una patología en este proceso (Morer et al.14). El lector sabe que Griselda visita cotidianamente la casa que habitó mientras su esposo vivía, el lugar donde lo esperó por última vez y, más importante, donde depositó sus ojos, elemento que es introducido y que termina de delinear el cauce simbólico de los ojos.

La metamorfosis está a punto de totalizarse y, como en los cuentos previos, es un acto siniestro. Como un prolegómeno, que ya se advertía previamente, los olores del jardín acusan el trocamiento de los ojos de Griselda: "Martha no deseaba sino huir cuanto antes de aquella mujer, del trágico jardín ya en sombras y del denso perfume que la envolvía” (203). Justo en el instante en que Martha se da cuenta que todo a su alrededor se modifica y que necesita escapar se completa la transformación de los ojos ausentes:

La mujer dejó de llorar y alzó la cara. Martha contempló entonces un rostro transfigurado por el dolor y dos enormes cuencas vacías; mientras los ojos de Griselda, cientos, miles de ojos, lirios en el estanque, la traspasaban con sus inmensas pupilas verdes, azules, grises, y después la perseguían apareciendo por todos lados como tratando de cercarla. (204) 
Los ojos metamorfoseados en lirios recuerdan, por su multiplicidad, a la descomposición de la psique y aluden a lo demoniaco, por disgregarse suprimiendo su natural número par (Cirlot 340), mientras que los lirios poseen una relación especial con lo subterráneo, como puerta del infierno (Chevalier 651). Pueden entenderse estos rasgos, a la luz de la diégesis, como análogos al infierno interno de la protagonista. Todo el jardín y la casa entera son, en cierto modo, el reflejo de su ser doloroso e inconsolable. La metamorfosis de los ojos, particularmente, en flores demuestra un contraste con los dos cuentos previos (sapo, gusano, cenizas) pues, aunque los lirios se relacionen con sentimientos negativos, finalmente son algo bello, bello y siniestro al mismo tiempo, pero es que la naturaleza compagina ambas cualidades. Que sean flores, en lugar de batracios o gusanos, podría indicar que, al contrario de las otras mujeres, Griselda cumplió su papel hasta el último momento como una esposa abnegada que, en el desequilibro de su dolor, atenta contra sí misma para guardar el recuerdo último con su esposo y para que no se le generaran nuevos, ya que el visitar su casa es vivir laberínticamente el mismo instante de aquella noche de tormenta una y otra vez.

\section{Palabras finales}

Las mujeres que pueblan los cuentos de Amparo Dávila son diversas, pero las conecta el horror de la vida cotidiana que se les impone. En el espacio estético que otorga la ficción, en las posibilidades del afluente que verbaliza relaciones tormentosas, maternidades indeseadas y vidas que se cortan intempestivamente, las mujeres modifican sus formas, se vuelven animales, flores o cenizas, pero reaccionan siempre, sin permanecer impávidas y pasivas ante sus prisiones femeninas. Este acercamiento crítico a tres cuentos de pulida filigrana muestra, solamente, una posibilidad para develar los símbolos soterrados que yacen en las profundidades de la narrativa compleja de una escritora prodigiosa que supo mirar el horror que emana de los días cotidianos, de los instantes banales y de las vidas más comunes para exponer que, aun en el horror de la vida, acontece la posibilidad del cambio. 


\section{Bibliografía}

Álvarez Rivera, Adriana. "La aparición del miedo en las rendijas de 'La quinta de las celosías"'. Revista Crítica de Narrativa Breve, no. 3, 2011, pp. 1-6, ojs.elte.hu/index.php/lejana/article/view/34/27 Chevalier, Jean. Diccionario de los símbolos. Herder, 1986.

Cirlot, Juan Eduardo. Diccionario de simbolos. Labor, 1992.

Dávila, Amparo. Cuentos reunidos. Fondo de Cultura Económica, 2018.

Durand, Gilbert. Las estructuras antropológicas del imaginario. Fondo de Cultura Económica, 2012.

. "La mitocrítica paso a paso". Traducción de Blanca Solares. Acta sociológica. no. 57, enero-abril 2012, pp. 105-118.

Esteinou, Rosario. "Las relaciones de parejas en el México moderno". Casa del tiempo, vol. III, no. 26, 2010, pp. 65-75, uam.mx/ difusion/casadeltiempo/26_27_iv_dic_ene_2010/casa_del_ tiempo_eIV_num26_27_65_75.pdf

Gamboa, Federico. Santa. Fondo de Cultura Económica, 2006.

García Peña, Lilia. Etnoliteratura. Principios teóricos para el análisis antropológico del imaginario simbólico mítico. Universidad de Colima, 2007. "El momento analógico del texto literario: hacia una lectura de los símbolos". La obra de arte literaria. Aproximaciones teóricas, coordinado por Gloria Vergara y Hilda Leal, Praxis, 2011, pp. 25-36.

Greimas, Algirdas Julius. Semántica estructural. Gredos, 1987.

Gutiérrez Piña, Claudia. "Amapolas deshojadas o el horror de la maternidad. 'El último verano' de Amparo Dávila”. Literatura Mexicana, vol. 29, no. 2, 2018, pp. 133-151, doi: http://dx.doi. org/10.19130/iifl.litmex.29.2.2018.1133.

Luna Chávez, Marisol y Víctor Díaz Arciniega. "La rutina doméstica como figuración siniestra en la obra de Amparo Dávila". Sincronía. Revista de Filosofía, Letras y Humanidades, no. 74, 2018, pp. 205-233, sincronia.cucsh.udg.mx/pdf/74/205-233_2018b.pdf

Martos-López, Isabel M., et al. "Duelo por muerte perinatal, un duelo desautorizado". Revista Española de Comunicación en Salud, vol. 
7, no. 2, 2016, pp. 300-309, doi: http://dx.doi.org/10.20318/ recs.2016.3454

Morer Bamba, Bárbara, et al. "El duelo y la pérdida en la familia. Revisión desde una perspectiva relacional”. Redes, no. 36, 2017, pp. 11-24, www.redesdigital.com.mx/index.php/redes/article/ view/196/159

Oliveras de Ita, Daniel. "La vida doble: nahualismo, brujería y terapéutica ritual en la chinantla media". Elpoder de saber. Especialistas rituales de México y Guatemala, coordinado por Patricia Gallardo Arias y François Lartigue, UNAM / Instituto de Investigaciones Históricas, 2015, pp. 155-172.

Quilodrán, Julieta. "Hacia un nuevo modelo de nupcialidad: ¿qué parejas y qué familias en el siglo XXI?". Los grandes problemas de México. Población, coordinado por Manuel Ordorica y JeanFrançois Prud'homme, El Colegio de México, 2012, pp. 40-50, libros.colmex.mx/wp-content/plugins/documentos/descargas/Ia.pdf 